\title{
Raskasmetallit ravintokasveissa ja maassa
}

\author{
J. E. HÅRDH \\ Helsingin yliopiston puutarhatieteen laitos
}

The heavy metals in alimentary crops and in soils

\author{
J. E. HẢrDH \\ Institute of Horticulture, University of Helsinki, Viik, Helsinki 71, Finland
}

\begin{abstract}
The contents of $\mathrm{Pb}, \mathrm{Cd}, \mathrm{Hg}, \mathrm{Cu}, \mathrm{Zn}, \mathrm{Mn}, \mathrm{V}, \mathrm{As}$ and $\mathrm{S}$ were studied on three vegetables cultivated at different distances from polluting sources and in clean. background areas without industry, housing or heavy traffic. The plants were lettuce, spinach and carrot. The usual forest-grown native alimentary berries of Vaccinium myrtillus, Vaccinium vitis-idaea, and mushrooms of the genera Boletus and Cantharellus, not far from the test plots, were likewise studied. At the same points ley grass and soil analyses were performed. Fertilizing experiments, and rinsing tests on the contents of lettuce, spinach and carrot were also made.

The test plots were on known distances from polluting industrial plants, the soil types, the soil $\mathrm{pH} / \mathrm{CaCl}_{2}$, and the distances from the sources are given. The heavy metals were extracted with $\mathrm{HNO}_{3}$ conc., As was analyzed using colorimetric determination, and $\mathrm{S}$ gravimetrically.

The background level of lead contents in soil was from 2.5 to $8.9 . \mathrm{mg} / \mathrm{kg}$ of dry matter. The contents of lettuce, spinach, and of carrot grown at same soils were $0.15-3.58$, $0.75-2.19$, and $0.31-1.74 \mathrm{mg} / \mathrm{kg} \mathrm{d}-\mathrm{m}$. The highest contents on soil, lettuce, spinach, and carrot were correspondingly, $187.1-999.7,5.50-198.75,3.65-52.60$ and $0.25-0.65 \mathrm{mg} / \mathrm{kg} \mathrm{d}-\mathrm{m}$. The lead on mushrooms in polluted localities was abundant, max. $149.9 \mathrm{mg} / \mathrm{kg}$ d-m.

It is evident that the soils with high organic matter contents had higher levels of $\mathrm{Pb}$ than soils of the same locality with lower organic matter contents. The soil $\mathrm{pH}$ did not markedly affect the contents of crops.

The cadmium content of the soil varied from 0.01 to $0.69 \mathrm{mg} / \mathrm{kg} \mathrm{d}-\mathrm{m}$., and the $z i n c$ content from 8.4 to $1301.3 \mathrm{mg} / \mathrm{kg} \mathrm{d}-\mathrm{m}$. The highest levels were seen in the city areas. The background levels of $\mathrm{Cd}$ were $0.01-0.05$, and of $\mathrm{Zn} 21.3-40.2 \mathrm{mg} / \mathrm{kg} \mathrm{d}-\mathrm{m}$. Lettuce had the highest metal contents of the vegetables tested, as had mushrooms of the native plants. Liming diminished the $\mathrm{Cd}$ content of lettuce, $\mathrm{K}$ and $\mathrm{Mg}$ fertilization did not have any effect. The rinsing of lettuce by dipping it five times in water reduced the $\mathrm{Cd}$ content by $44 \%$. The zinc level of grass was high, $23.7-211.6 \mathrm{mg} / \mathrm{kg} \mathrm{d}-\mathrm{m}$.

The mercury contents of the cultivated soils varied from 0.03 to $0.86 \mathrm{mg} / \mathrm{kg} \mathrm{d}-\mathrm{m}$., of forest soils from 0.04 to $0.09 \mathrm{mg} / \mathrm{kg} \mathrm{d}-\mathrm{m}$. No marked differences could be seen in the $\mathrm{Hg}$ contents of the different plant species studied. The highest levels were in the polluting areas.
\end{abstract}


The background level of copper in the soil was $4.6-17.7 \mathrm{mg} / \mathrm{kg}$. The highest levels were noted in the vicinity of a copper mine and in the immission areas. Lettuce and spinach had higher contents than carrot, mushrooms the highest of all the plants studied.

The highest arsenic levels in the soil were close to industrial sources and alongside main roads, the contents varied from 0.47 to $10.80 \mathrm{mg} / \mathrm{kg} \mathrm{d}-\mathrm{m}$. The As content of lettuce was $0.11-2.68$, of spinach $0.95-1.75$, of carrots $0.09-2.90$, of berries $0.15-0.61$ and of mushrooms $0.20-0.95 \mathrm{mg} / \mathrm{kg} \mathrm{d}-\mathrm{m}$. Grass contained high As in some ares.

The contents of total sulphur are given. The Mn and $\mathrm{V}$ contents were also studied in some localities.

Maahan ja kasveihin voi joutua raskaita metalleja ja niiden kaltaisia aineita 1. epäpuhtauksina lannoitteiden mukana, 2. hivenravinneseoksissa, 3 . karjanlannassa, johon karjan ravintoon lisätyt hivenmetallit ovat keräytyneet, 4. kasvinsuojeluaineissa, 5. viemärilietteen mukana, sekä 6. teollisuudesta, taajamista ja moottoriliikenteestä peräisin olevina laskeumina. Lisäksi on osa näistä aineista peräisin peruskallion ja maan sluontaisesta" pitoisuudesta sekä globaalisesta saastunnasta. Kun monien raskasmetallien ja niiden yhteydessä leviävien ja vaikuttavien ei-metallien määrät ympäristössä näyttävät ihmisen toiminnan ansiosta lisääntyvän, on tarpeen tehdä tutkimusta ja seurantaa saastepitoisuuksien kartoittamiseksi.

Ravintokasvien saastepitoisuuksista on Suomessa olemassa yksittäistietoja, ja muista maista tietoja eräiden tutkimuslaitosten alueellaan suorittamien selvitysten tai kansainvälisten työryhmien kokoamien lukujen perusteella (Dissing 1972, Kloke 1972, Vetter et al. 1973, BouQuiaux 1973, Ødelien 1974, McLean 1976 etc.) Maan metallipitoisuuksia on Pohjoismaissa selvitetty useilla paikkakunnilla (LÅg 1972, Hvatum 1972, ERviö \& LAKAneN 1973, RAUtAPÄÄ 1973 etc.), mutta alueellista vertailevaa tutkimusta ravintokasvien ja niiden kasvualustan pitoisuuksista ei maassamme ole tähän mennessä olemassa. Tämän selvityksen tarkoituksena on määrittää eräiden teollisuuskeskusten, asutustaajamien ja liikenneväylien vaikutusta ravintokasvien ja niiden kasvupaikan raskasmetallien ja niiden tavoin esiintyvien aineiden pitoisuuksiin. Lisäksi oli vertailukohteina vastaavia määrityksiä "puhtaiksi» oletetuilta alueilta eri osissa Suomea. Tutkimus suoritettiin vuosina 19741976 osittain Suomen Akatemian myöntämin määrärahoin. Koeruutujen hoidosta sekä näytteiden otosta ja lähettämisestä huolehtivat Suomen $4 \mathrm{H}$ liiton ja Finlands Svenska 4H:n toimihenkilöt sekä kokeidenhoitajat. Analyysityö tapahtui Viljavuuspalvelu Oy:ssa Helsingissä.

\section{Aineisto}

Kaikkiaan 52:lle paikkakunnalle perustettiin $3 \times 3 \mathrm{~m}$ koealat, jotka lannoitettiin tarkoin samalla tavalla $(11-25-22$ seosta $500 \mathrm{~kg} / \mathrm{ha}+$ pintalannoitteena Oulun salpietaria $70 \mathrm{~kg} / \mathrm{ha}$ ) ja kylvettiin niihin samaa lajiketta olevat kaistat salaattia cv 'Market Favorite', pinaattia cv 'Medania' ja porkkanaa cv 'Fancy'. Samalla annettiin avustaville henkilöille ohjeet ja pakkaukset näytteiden ottamista ja lähettämistä varten. Kutakin kasvia otettiin kaksi rinnakkaisnäytettä niidon tavanomaisessa korjuuvaiheessa, niiden ravintona käytettävät osat pestiin juoksevassa vedessä ja lähetettiin labora- 
torioon. Kasvien kasvupaikalta otettiin kaksi maanäytettä ruokamultakerroksesta $0-15 \mathrm{~cm}: n$ syvyydestä. Lisäksi kerättiin kulloinkin läheisimmästä metsästä kaksi rinnakkaista puolukka-, mustikka-, sieni- ja metsämaanäytettä. Sienet olivat joko tatteja tai keltavahveroita. Eräillä koepaikoilla otettiin vielä kaksi rinnakkaista laidunruohonäytettä.

Tikkurilassa, Karlebyssä, Halkokarissa, Vihdissä, Orimattilassa ja Ilomantsissa järjestettiin lannoituskokeet tarkoituksena selvittää kalkituksen $(6000 \mathrm{~kg} / \mathrm{ha})$, kaliumsulfaatti- $(600 \mathrm{~kg} / \mathrm{ha})$ ja magnesiumsulfaattilannoituksen $(1578 \mathrm{~kg} / \mathrm{ha})$ vaikutusta kasvien raskasmetallipitoisuuksiin. Lisäksi suoritettiin saasteisilla koepaikoilla Tikkurilassa ja Halkokarissa pesukokeet, joissa selvitettiin juoksevassa vedessä sekä viidesti upottamalla tapahtuvan pesun vaikutusta salaatin pitoisuuksiin. Mainituista paikkakunnista Ilomantsi oletettiin puhtaaksi "taustapaikkakunnaksi», muut teollisuuden tai liikenteen vaikutuksen alaisiksi. Lannoitus- ja pesukokeista, kuten muuallakin, otettiin kasveista ja maasta kaksi rinnakkaisnäytettä.

\section{Menetelmät}

Maanäytteistä määritettiin maalaji, orgaanisen aineksen pitoisuus, $\mathrm{pH}$ $\mathrm{CaCl}_{2}$-uutteesta, $\mathrm{HNO}_{3}$ :hon liukoiset ainepitoisuudet sekä lannoituskokeista maan johtoluku vesiuutteesta 1:2.5. Sekä maasta että kasveista ilmaistaan metalli- ja As-pitoisuudet $\mathrm{mg} / \mathrm{kg}$ kuiva-aineesta, rikin pitoisuus $\mathrm{g} / \mathrm{kg} \mathrm{k}$-a.

$M n, C u, Z n$. Maa- ja kasvinäytteet: $10 \mathrm{~g}$ :n näytteen kuivapoltto $550^{\circ}$ :ssa, uutto $10 \mathrm{ml}$ :ssa kiehuvaa $5 \% \mathrm{HNO}_{3}+2 \mathrm{ml} \mathrm{H}_{2} \mathrm{O}_{2}$, määritys AAS Perkin Elmer 303:lla käyttäen liekki-ilmaisinta.

$\mathrm{Pb}$ ja $\mathrm{Cd}$. Kuten edellä, mutta käyttäen AAS:ssa grafiittikyvettiä (Statens Lantbrukskemiska Laboratorium 1974).

$V$. $\mathrm{HNO}_{3}$-uutteen konsentrointi käyttäen pyrrolidini-ditiokarbamaattihappoa, määritys AAS:lla liekki-ilmaisinta käyttäen (LAKANEN 1966).

As. Kolorimetrinen määritys, mikä perustuu hopeadietyliditiokarbamaatin värjäytymiseen $\mathrm{AsH}_{3}$ :lla (Official Methods of Analysis 1965: 356).

$H g$. Uutto kylmänä $\mathrm{HNO}_{3}$ conc: $\mathrm{CrO}_{3} 5 \%(2: 10)$, analyysi AAS:lla ilman liekki-ilmaisinta (Bouchard 1973).

$S$ määritettiin gravimetrisesti $\mathrm{BaSO}_{4}$-sakkana (Official Methods of Analysis 1965: 106).

\section{Tulokset}

Lyijy $\mathrm{Pb}$. Ravintokasvien lyijypitoisuuksista on eri maista lukuisia tietoja olemassa. OECD:n suorittaman kiertokyselyn mukaan (BouQuiaux 1973) on Saksan Liittotasavallassa havaittu lyijyä keräkaalissa $0.03-9.7 \quad( \pm 1.2)$ $\mathrm{mg} / \mathrm{kg}$ tp., Belgiassa 0.12-0.14 ( \pm 0.13$)$ ja Englannissa 0.01-0.51 ( \pm 0.08$)$. Salaatissa on Saksassa mitattu $0.16-6.00$ ( \pm 1.04 ), pinaatissa $0.01-0.95$ ja porkkanassa $0.02-0.23( \pm 0.07) \mathrm{mg} / \mathrm{kg}$ tp. Paikkakuntaa tai etäisyyttä saastelähteestä ei näissä tapauksissa ole ilmoitettu. Nordenhamin alueella 70 vuotta paikkakunnalla toimineen lyijynjalostustehtaan lähellä on mitattu 1 
km:n etäisyydellä tehtaasta salaatissa $27-198$, keräkaalissa $12-41$ ja viljelymaassa $729-3410 \mathrm{mg} / \mathrm{kg}$ k-a., $3 \mathrm{~km}: n$ etäisyydellä tehtaasta länteen, pääasiallisen tuulen suuntaan, vastaavasti $12-25,11-20$ ja $175-190 \mathrm{mg} / \mathrm{kg} \mathrm{k}$-a. Salaatin pesu vähensi lyijypitoisuutta 38-63\%:lla (VETTER et al. 1973). Maailman terveysjärjestön WHO:n ehdottama enimmäisraja lyijylle ihmisellä on 3-4 mg/vk. Suomessa ovat ERviö ja LAKAnen (1973) todenneet Tikkurilassa $0-490 \mathrm{~m}: n$ päässä lyijytehtaasta liukoista $\mathrm{Pb}$ maassa $53-985 \mathrm{mg} / \mathrm{l}$ ja 8-33 km:n päässä $2-10 \mathrm{mg} / \mathrm{l}$. Suomessa on todettu peltomaiden keskimääräiseksi kokonaislyijypitoisuudeksi $16 \mathrm{mg} / \mathrm{kg}$, kivennäismailla 6-60 ja eloperäisillä mailla $0-40 \mathrm{mg} / \mathrm{kg}$. WARnusz (1973) totesi Saksassa maassa ruokamultakerroksessa lyijyä $65 \mathrm{~m}: n$ päässä vilkkaasti liikennöidystä moottoritiestä (75000 autoa/vrk) $67 \mathrm{mg} / \mathrm{kg}$ ik. painoa, $120 \mathrm{~m}: \mathrm{n}$ päässä siitä 17 $\mathrm{mg} / \mathrm{kg}$. Purves (1972) havaitsi Skotlannissa kaupunkitarhamaassa $11.2 \mathrm{mg} / \mathrm{kg}$ ik. $\mathrm{Pb}$ ja maaseudulla peltomaassa $0.65 \mathrm{mg} / \mathrm{kg}$ ik. Dano-kompostissa siellä oli $215 \mathrm{mg} / \mathrm{kg} \mathrm{Pb}$. Norjassa on alueita, joilla korkean luontaisen lyijypitoisuuden $(2.5 \%)$ vuoksi ei ole mitään kasvillisuutta (LÅG 1972). Myös lukuisia muita tutkimuksia on julkaistu teollisuuslaitosten, taajamien sekä moottoriajoneuvoliikenteen levittämän $\mathrm{Pb}$-saasteen määristä.

Tämän tutkimuksen puitteissa todettiin koepisteissä eri puolilla maata suuria eroja happoliukoisen lyijyn pitoisuuksissa. "Puhtaina" tausta-alueina pidetyillä paikkakunnilla Pertunmaan Laukkalan kylässä (koepaikka n:o 8), Punkasalmella (n:o 9), Puumalassa (n:o 10), Kaustisissa (n:o 27), Sallassa (n:o 29), Inarissa (n:o 31), Ilomantsissa (n:o 32), Rovaniemen mlk:ssa (n:o 45), Saarijärvellä (n:o 48) ja Maaningalla (n:o 51) olivat viljelymaan pitoisuudet $2.5-8.9 \mathrm{mg} / \mathrm{kg} \mathrm{k}$-a. Salaatin pitoisuuksina oli vastaavilla alueilla $0.15-3.58$, pinaatin $0.75-2.19$ ja porkkanan $0.31-1.74 \mathrm{mg} / \mathrm{kg} \mathrm{k}-\mathrm{a}$.

Korkeimpia lyijypitoisuuksia havaittiin Tikkurilassa (n:o 2), Tuirassa (n:o 16) ja Viikinmäessä (n:o 44). Näissä kohdissa olivat viljelymaan pitoisuudet kolmen vuoden keskiarvolukuina $187.1-583.7 \mathrm{mg} / \mathrm{kg}$, salaatin vastaavilla kohdilla $5.50-198.75$, pinatin $3.65-52.60$ ja porkkanan $0.25-0.65$. Todetaan, että harvoja saastuneita kohtia lukuunottamatta, jotka sijaitsevat lähempänä kuin $5 \mathrm{~km}: n$ säteellä saastuttavasta teollisuuslaitoksesta tai välittömästi vilkasliikenteisen moottoritien varressa (n:o 44), olivat pitoisuudet maassamme keskimäärin alhaisempia kuin useat julkaistut tiedot KeskiEuroopasta. Luvut eri maista ovat kuitenkin vaikeasti toisiinsa verrattavissa saastuntaolosuhteiden ja analyysimenetelmien erilaisuudesta johtuen. Metsästä kerätyistä ravintokasveista olivat puolukan $\mathrm{Pb}$-pitoisuudet hieman mustikan pitoisuuksia alhaisemmat, sienten korkeimmat, jopa $149.9 \mathrm{mg} / \mathrm{kg}$ k-a (n:o 2). Viljelykasveista salaatin pitoisuudet olivat korkeimmat. Vaikka pitoisuudet eri koealoilla vaihtelivat suuresti, näyttivät ravintokasvien ja niiden kasvualustan lyijypitoisuudet olevan toisiinsa vuorosuhteessa.

Lannoituskokeiden tulokset kahden kerranteen keskiarvcina esitetään taulukossa 1. Milloin lannoittamattoman maan $\mathrm{pH}$ ylitti 6.0:n, ei kalkituksella ollut sanottavaa vaikutusta kasvien $\mathrm{Pb}$-pitoisuuksiin, happamemmassa maassa Tikkurilassa sen sijaan oli. Pesukokeessa (taulukko 2) voitiin viidesti upottamalla veteen vähentää salaatin $\mathrm{Pb}$-pitoisuutta $38 \%$ :lla. Maan $\mathrm{Pb}$-pitoisuuksissa eri etäisyyksillä Turun ja Lahden moottoriteistä ei ollut selvää liiken- 


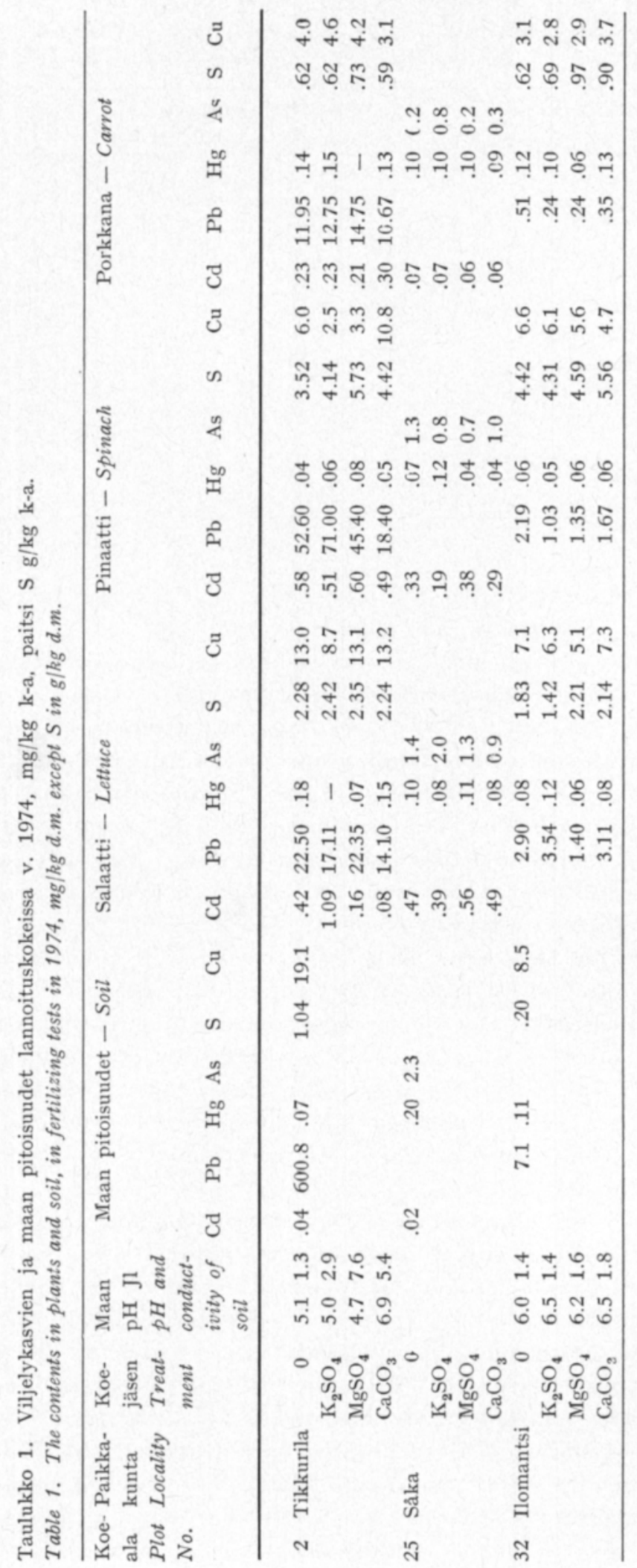


Taulukko 2. Salaatin pitoisuudet pesukokeissa v. $1974, \mathrm{mg} / \mathrm{kg} \mathrm{k}$-a, paitsi S g/kg k-a. Table 2. The contents of lettuce in tests on washing in 1974, mg/kg d.m. except $S$ in g/kg d.m.

\begin{tabular}{|c|c|c|c|c|c|c|c|c|}
\hline \multirow{2}{*}{$\begin{array}{l}\text { Koeala } \\
\text { Plot No. }\end{array}$} & \multirow{2}{*}{$\begin{array}{c}\text { Paikkakunta } \\
\text { Locality }\end{array}$} & \multirow{2}{*}{$\begin{array}{l}\text { Käsittely } \\
\text { Treatment }\end{array}$} & \multicolumn{6}{|c|}{ Salaatti - Lettuce } \\
\hline & & & $\mathrm{Cd}$ & $\mathrm{Pb}$ & As & $\mathrm{Cu}$ & $\mathrm{Hg}$ & $\mathrm{S}$ \\
\hline \multirow[t]{3}{*}{3} & Tikkurila & $\begin{array}{l}\text { ei pesty } \\
\text { unwashed }\end{array}$ & .35 & 5.3 & & 13.0 & & 2.4 \\
\hline & & $\begin{array}{l}\text { upotuspesu } \\
\text { dipped }\end{array}$ & .19 & 3.3 & & 15.2 & & 2.1 \\
\hline & & $\begin{array}{l}\text { juokseva vesi } \\
\text { running water }\end{array}$ & .23 & 4.9 & & 32.5 & & 2.5 \\
\hline \multirow[t]{3}{*}{21} & Halkokari & $\begin{array}{l}\text { ei pesty } \\
\text { unwashed }\end{array}$ & .83 & & 2.8 & & .099 & \\
\hline & & $\begin{array}{l}\text { upotuspesu } \\
\text { dipped }\end{array}$ & .48 & & 2.0 & & .081 & \\
\hline & & $\begin{array}{l}\text { juokseva vesi } \\
\text { running water }\end{array}$ & .89 & & 0.6 & & .257 & \\
\hline
\end{tabular}

teen vaikutusta, sen sijaan lehtivihannesten pitoisuudet näyttivät olevan toisinaan korkeimmat tien reunasta $5 \mathrm{~m}: \mathrm{n}$ päässä (taulukko 3 ).

Kadmium $C d$ ja sinkki $Z n$ on viime vuosina todettu terveydelle haitallisiksi raskasmetalleiksi. Niiden määrät maassa saattavat lisääntyä teollisuuden ja moottoriliikenteen päästöjen johdosta sekä viemärilietteen ja lannoitteiden mukana. Fosfaattilannoitteiden Cd-pitoisuus johtuu raakafosfaatista, jossa sitä on 5-100 ppm (Williams \& David 1976). Suomessa on Rauta$P \ddot{A} A ̈$ (1973) todennut superfosfaatin Cd-pitoisuudeksi noin 1.9 ppm, mutta tämä saattaa vaihdella raakafosfaattilähteiden muuttuessa. Kun kasvien kadmiuminotto lisää myös niiden sinkinottoa, on näiden metallien yhteisvaikutus terveydelle haitallisena otettava huomioon (MCLEAN 1976).

Maan keskimääräinen taustapitoisuus Kanadassa on ollut $0.56 \mathrm{ppm} \mathrm{Cd} \mathrm{ja}$ $53.5 \mathrm{ppm} \mathrm{Zn}$ sekä Saksassa 0.34 Cd ja $35.0 \mathrm{Zn}$ (KLOKE 1972). Saksassa on 1 $\mathrm{km}: \mathrm{n}$ etäisyydellä lyijytehtaasta todettu maassa ruokamultakerroksessa 40 ppm Cd ja 3000 ppm Zn sekä $6 \mathrm{~km}: n$ päässä tehtaasta $1.0 \mathrm{ppm} \mathrm{Cd} \mathrm{ja} 90$ ppm Zn (VETter et al. 1973). Viemärilietteessä on Saksassa todettu $950 \mathrm{ppm}$ k-a. kadmiumia (Warnusz 1973), Suomessa 2.4-710 ppm k-a. Suomessa on todettu maassa $0.01-0.7 \mathrm{ppm} \mathrm{k}$-a. Cd ja viljakasveissa $0.01-1.0 \mathrm{ppm}$ k-a. (Nylands sv. lantbr. sällsk. 1973).

Kadmiumin oletetaan korvaavan ihmisen luustossa kalsiumia ja siten akkumuloituvan ruumiiseen, sen sijaan sinkki erittyy nopeasti elimistöstä. WHO:n suosittelema toleranssiraja Cd:lle ravinnossa on $\mathbf{0 . 4}-\mathbf{0 . 5} \mathrm{mg} /$ viikko. Ihminen saa ravinnossaan sinkkiä esim. Norjassa $12-15 \mathrm{mg} / \mathrm{pv}$, mutta huomattavan suuret määrät aiheuttavat akuutin myrkytystilan (ØDELIEN 1974). Saksassa on vihanneksissa todettu $0.03-0.32 \mathrm{ppm}$ tp. Cd, salaatissa Englannissa $0.04-5.70 \mathrm{ppm}$ tp. Sinkkiä on vastaavasti Saksassa havaittu 3.7017.25 ja Belgiassa vihanneksissa $0.70-6.50 \mathrm{ppm}$ tp. (BouQuiaux 1973). Suomessa on jäkälässä todettu kadmiumia Ykspihlajassa 1.10 ppm k-a., Kokkolassa $0.94-1.06$, Kaamasessa 0.43 ja Hetassa $0.05-0.38$ ppm k-a. (JAAKKOLA et al. 1973). 
Taulukko 3. Maan ja kasvien $\mathrm{Pb}$ - ja S-pitoisuudet moottoriteiden varrella.

Table 3. The contents of $\mathrm{Pb}$ and $S$ on soil and plants alongside main roads.

\begin{tabular}{|c|c|c|c|c|c|c|c|c|c|}
\hline Koeala & Koepaikka & Etäisyys tien & Salaatti & ettuce & Pinaatti & Spinach & Porkkan & Carrot & Maa-Soil \\
\hline Plot No. & Locality & $\begin{array}{c}\text { reunasta } \mathrm{m} \\
\text { Distance from } \\
\text { road } m\end{array}$ & $\begin{array}{c}\mathrm{Pb} \\
\mathrm{mg} / \mathrm{kg}\end{array}$ & $\begin{array}{c}\mathrm{S} \\
\mathrm{g} / \mathrm{kg}\end{array}$ & $\begin{array}{c}\mathrm{Pb} \\
\mathrm{mg} / \mathrm{kg}\end{array}$ & $\begin{array}{c}\mathrm{S} \\
\mathrm{g} / \mathrm{kg}\end{array}$ & $\begin{array}{c}\mathrm{Pb} \\
\mathrm{mg} / \mathrm{kg}\end{array}$ & $\begin{array}{c}\mathrm{S} \\
\mathrm{g} / \mathrm{kg}\end{array}$ & $\begin{array}{cl}\mathrm{Pb} & \mathrm{S} \\
\mathrm{mg} / \mathrm{kg} & \mathrm{g} / \mathrm{kg}\end{array}$ \\
\hline
\end{tabular}

Lahdentie,

Orimattila

$\begin{array}{rrrrrrrrr}5 & 5.28 & 2.11 & 2.82 & 3.45 & 0.35 & 0.93 & 12.2 & 0.20 \\ 30 & 3.69 & 1.90 & 1.34 & 3.07 & 0.55 & 6.77 & 13.5 & 0.21 \\ 100 & 2.13 & 2.04 & 1.99 & 1.62 & C .31 & 0.70 & 12.9 & 0.18 \\ 150 & 3.16 & 2.11 & 2.96 & 2.31 & 0.39 & 0.66 & 13.1 & 0.24\end{array}$

Turuntie,

Vihti

\begin{tabular}{rrrrrrrrrr}
38 & 5 & 8.02 & 2.66 & 3.42 & 2.80 & 0.39 & 0.53 & 11.2 & 0.32 \\
39 & 30 & 1.24 & 3.31 & 1.15 & 3.24 & 6.26 & 0.42 & 6.4 & 0.07 \\
40 & 100 & 1.52 & 1.52 & 1.45 & 3.49 & 0.18 & 0.51 & 6.5 & 0.38 \\
41 & 150 & 1.12 & 2.38 & 1.74 & 1.80 & 0.15 & 0.41 & 15.2 & 0.42 \\
\hline
\end{tabular}

Tuloksista havaitaan (liitteet 2 ja 4), että viljelymaan Cd-pitoisuudet vaihtelivat $0.01-0.69$ ja $\mathrm{Zn}$-pitoisuudet $8.4-1301.3 \mathrm{mg} / \mathrm{kg} \mathrm{k}$-a., korkeimmat pitoisuudet olivat koealueilla Helsingin (n:o 44), Tampereen (n:o 11), Oulun (n:o 16 ja 18) ja Raision (n:o 47) seuduilla. Korkeimmat salaatin, porkkanan ja sienten pitoisuudet olivat Helsingin (n:o 44), Tikkurilan (n:o 2-3) ja Oulun (n:o 16-18) koealueilla. Myös Tampereen pohjoispuolella (n:o 12 ja 13) oli korkeita sienten Cd-pitoisuuksia. Lannoituskokeissa (taulukko 1) näytti kalkitus vähentävän salaatin Cd:n ottoa, muilla kasveilla ei eroa ollut eikä K- tai Mg-lannoituksella ollut selvää vaikutusta kasvien Cd-pitoisuuksiin. Pesukokeissa (taulukko 2) upotuspesu vähensi salaatin Cd-pitoisuutta $44 \%: l l a$, juoksevassa vedessä suoritettu pesu ei vaikuttanut pitoisuuksiin.

Elohopea $\mathrm{Hg}$. Tuontitavarana maahan tulevasta elohopeasta n. $90 \%$ käytetään teollisuudessa, tästä määrästä Norjassa $7 \%$ hammaslääketieteessä ja $2.5 \%$ maataloudessa. Suomessa käytetään elohopeapitoisia kasvinsuojeluaineita vielä siementen peittauksessa, kärpästoukkien torjunnassa ristikukkaiskasveilla sekä puun haavojen suojaamisessa. Peittaus- ja maankäsittelyaineista on Kanadassa todettu jääneen elohopeaa viljelymaahan, sen pitoisuudet ovat siellä olleet $0.01-1.14 \mathrm{ppm} \mathrm{k}$-a. ja korkeimmat pitoisuudet on havaittu orgaanisessa maassa (FrANK et al. 1976). Vihannesten pitoisuudet olivat Kanadassa saman tutkimuksen mukaan 0.02-1.11 ppm k-a., Englannissa lehtivihanneksissa $0.03-0.9 \mathrm{ppm}$ k-a. ja Saksassa vihanneksissa vähemmän kuin 0.03 ppm (BouQUiaux 1973). Ihminen saa elohopeaa pääasiassa ravinnon mukana, Englannissa $10 \mu \mathrm{g} / \mathrm{pv}$ ja Norjassa 5-20 $\mu \mathrm{g} / \mathrm{pv}$. WHO:n suositus enimmäismäärästä on täysikäiselle ihmiselle $0.3 \mathrm{mg} /$ viikko, mistä enintään $0.2 \mathrm{mg}$ metylielohopeana.

Tuloksia Suomesta esitetään liitteessä 5, mistä ilmenee, että viljelymaan pitoisuudet olivat $0.03-0.86 \mathrm{ppm}$ k-a., korkeimmat pitoisuudet Helsingin (n:o 44), Kokkolan (n:o 24-26) ja Oulun koealueilla (n:o 16). Korkeimmat 
metsämaan pitoisuudet olivat $0.06-0.09$, salaatin $0.12-0.13$, pinaatin 0.08 ja metsämarjojen $0.04 \mathrm{ppm}$. Sienten $\mathrm{Hg}$-pitoisuudet tutkituissa tapauksissa olivat alhaisia.

Kupari Cu. Kupari, samoin kuin sinkki, ovat kasvien, eläinten ja ihmisen tarvitsemia mineraaleja. Kuparimyrkytyksiä tunnetaan kuitenkin kotieläimillä tapauksissa, missä maan $\mathrm{HNO}_{3}$-liukoisen kuparin pitoisuus on ollut yli $34.6 \mathrm{mg} / \mathrm{kg} \mathrm{k}$-a. ja ruohon $14.0 \mathrm{mg} / \mathrm{kg} \mathrm{k}$-a. (Hemkes \& Hartmans 1974). Kanadassa havaittiin orgaanisen maan sisältävän 29.5-111.0 ja hiekkamaan 2.1-123.0 ppm k-a. $\mathrm{HNO}_{3}$-liukoista $\mathrm{Cu}$. Vastaavasti oli vihanneksissa 29.5111.0 ja 3.1-144.0 ppm k-a. (Frank et al. 1976). Saksassa on havaittu maan pintakerroksessa $\mathbf{0 - 5} \mathrm{cm}: n$ syvyydessä $1 \mathrm{~km}: n$ päässä lyijysulattamosta 70 $\mathrm{mg} / \mathrm{kg}$ ilmakuivaa ainetta ja $6 \mathrm{~km}: n$ päässä siitä $8 \mathrm{mg} / \mathrm{kg}$ (VETTER et al. 1973). Vastaavasti havaittiin salaatissa $9.3-15.0$ ja $6.6-9.4$, porkkanassa $6.8-8.6$ ja $6.0-6.2$ sekä mansikoissa $0.63-0.41 \mathrm{ppm} \mathrm{k}-\mathrm{a}$. Baijerissa on todettu lehtivihanneksissa $3.7-17.2 \mathrm{ppm} \mathrm{k}-\mathrm{a}$. Cu.

Tuloksia tästä tutkimuksesta esitetään liitteessä 3. Havaitaan, että viljelymaan pitoisuudet vaihtelivat 4.6-69.9 ppm, korkeimmat pitoisuudet havaittiin Oulun (n:o 16), Tampereen (n:o 11), Tikkurilan (n:o 6) ja Raision alueilla (n:o 47). Salaatin pitoisuudet olivat korkeimmat Tikkurilassa (n:o 3-6) sekä Outokummun kaupungin alueella (n:o 49 ja 50). Sienten pitoisuudet olivat korkeimmat Outokummun (n:o 49 ja 50) alueella, Oulun pohjoispuolella (n:o 16-19) ja Punkasalmella (n:o 9). Metsämarjojen, porkkanan ja laidunruohon pitoisuudet olivat alhaiset.

Arseeni As. Maan arseenipitoisuutta saattavat lisätä kasvinsuojeluaineiden käyttö, lannoitteissa olevat epäpuhtaudet sekä teollisuudesta peräisin oleva laskeuma. Maassamme ei nykyisin käytetä arseenipitoisia kasvinsuojeluaineita, mutta jäämiä aikaisemmasta käytöstä saattaa vielä maassa olla.

Teollisuuden vaikutusta maan ja kasvien arseenipitoisuuteen osoittavat luvut mm. Saksassa Nordenhamin alueella. Siellä oli pesemättömässä lehtikaalissa 1 km:n päässä tehtaasta $1.96,2$ km:n päässä 1.73 ja 3 km:n etäisyydellä $0.60 \mathrm{As} \mathrm{mg/kg} \mathrm{k-a.} \mathrm{Vastaavasti} \mathrm{oli} \mathrm{pestyssä} \mathrm{lehtikaalissa} 1.12,1.15 \mathrm{ja}$ $0.34 \mathrm{mg} / \mathrm{kg} \mathrm{k}$-a. Hollannissa on todettu arseenia pinaatissa 0.1 , porkkanassa 0.01 ja keräkaalissa $0.45 \mathrm{mg} / \mathrm{kg}$ tp. (BouQuiaux 1973).

Viljelymaan, metsämaan sekä näillä kasvaneiden ravintokasvien As-pitoisuuksia Suomessa esitetään liitteessä 6. Maan pitoisuudet vaihtelivat $0.47-$ 10.80 ppm k-a., korkeimmat pitoisuudet olivat teollisuuden ja moottoriajoneuvoliikenteen välittömässä vaikutuspiirissä (n:ot 2, 16, 44). Salaatin (0.11$2.68 \mathrm{ppm})$, pinaatin $(0.95-1.75 \mathrm{ppm})$, porkkanan $(0.09-2.90 \mathrm{ppm})$, metsämarjojen $(0.15-0.61 \mathrm{ppm})$ ja sienien $(0.20-0.95 \mathrm{ppm})$ pitoisuudet vaihtelivat verrattain paljon ja olivat korkeimmat samoilla seuduilla kuin maan korkeimmai lukemat. Kalkituksella tai kali- ja magnesiumlannoicuksella ei näyttänyt olevan vaikutusta kasvien As-pitcisuuteen.

Rikki S. Maassa ja kasveissa oleva rikki on laskeumaa teollisuudesta ja moottoriajoneuvojen pakokaasuista sekä lannoitteiden, viemärilietteen tai kompostin mukana maahan tullutta sulfaattia tai muuta rikkiyhdistettä. Niinpä Pertunmaan perustasoasemaksi valitussa Laukkalan kylässä on suurin mitattu laskeuma ollut $150 \mathrm{mg} \mathrm{S} / 100 \mathrm{~m}^{2}$. kk, Kokkolassa saastuttavan 
metalliteollisuuden läheisyydessä $24.500 \mathrm{mg} \mathrm{S} / 100 \mathrm{~m}^{2}$. kk (LAAMANEN 1973). Alueellisesti suurimmat sadeveden sisältämät $\mathrm{SO}_{4}$-määrät, $250 \mathrm{mg} / \mathrm{m}^{2}$. kk on samassa tutkimuksessa todettu Varsinais-Suomessa, Etelä-Karjalassa, Satakunnassa ja Oulun eteläpuolella. Todetut rikkipitoisuudet eivät nykyisellään ole laajoja alueita tarkasteltaessa haitallisia, mutta laskeuman sekä sadeveden sisältämän $\mathrm{SO}_{4}: n$ määrät ovat kasvamassa ja vaikuttavat maan happamuutta lisäävästi.

Tässä tutkimuksessa (liite 7) todetut kokonaisrikkimäärät vihanneskasveissa vaihtelivat $0.42-4.59 \mathrm{~g} / \mathrm{kg} \mathrm{k}$-a., suurimmat määrät olivat keskimäärin pinaatissa Helsingin (n:o 1), Oulun (n:o 16, 17) ja Outokummun (n:o 49 ja 50) alueilla sekä Tikkurilassa (n:o 2 ja 3). Sienten pitoisuudet olivat korkeimmat Outokummun ja Oulun alueella, metsämarjojen pitoisuudet sen sijaan alhaisimmat, $0.50-1.75 \mathrm{~g} / \mathrm{kg} \mathrm{k}-\mathrm{a}$. Mustikassa cli kokonaisrikin määrä hieman suurempi kuin sitä happoisemmassa puolukassa. Lannoituskokeissa kalkitus näytti silloin, kun maan $\mathrm{pH}$ oli $>6.0$ (n:o 32), lisäävän salaatin, pinaatin ja porkkanan S-pitoisuutta, muulloin ei. Moottoritien vaikutus näiden kasvien S-pitoisuuteen eri etäisyyksillä ei ollut merkitsevä.

Vanadiini $V$. Määritysten yhteydessä selvitettiin myös $\mathrm{HNO}_{3}$-liukoisen $\mathrm{V}: \mathrm{n}$ pitoisuuksia ravintokasveissa ja maassa. Salaatin V-pitoisuudet vaihtelivat $0.05-0.50 \mathrm{ppm} \mathrm{k}-\mathrm{a}$., pinaatin $0.08-0.53$ ja porkkanan $0-0.52$. Vastaavissa kohdin oli viljelymaassa $12.4-50.7$ ppm k-a. Korkeimmat pitoisuudet havaittiin Tikkurilassa (n:o 3-6), Messukylässä (n:o 11) ja Oulun alueella (n:o 16-20) (taulukko 4).

Mangaani Mn. Viikissä sekä Tikkurilassa lyijynjalostustehtaiden läheisyydessä tehtiin myös happoliukoisen mangaanin määrityksiä. Suomessa esit-

Taulukko 4. Maan ja vihannesten V- ja Mn-pitoisuuksia, mg/kg k-a.

Table 4. Contents of $V$ and $M n$ in soil and vegetables, in mg/kg d.m.

\begin{tabular}{|c|c|c|c|c|c|c|c|c|c|}
\hline $\begin{array}{l}\text { Koeala } \\
\text { Plot } \mathrm{No} .\end{array}$ & $\begin{array}{c}\text { Paikkakunta } \\
\text { Locality }\end{array}$ & $\begin{array}{l}\text { Maa } \\
\text { V }\end{array}$ & $\begin{array}{r}- \text { Soil } \\
\text { Mn }\end{array}$ & $\begin{array}{c}\text { Salaatti } \\
\text { V }\end{array}$ & $\begin{array}{c}- \text { Lettuce } \\
\mathrm{Mn}\end{array}$ & $\begin{array}{c}\text { Pinaatti } \\
\text { V }\end{array}$ & $\begin{array}{c}\text { Spinach } \\
\text { Mn }\end{array}$ & $\begin{array}{c}\text { Porkkana } \\
\text { V }\end{array}$ & $\begin{array}{c}- \text { Carrot } \\
\text { Mn }\end{array}$ \\
\hline 1 & Viikki & 17.4 & 188.0 & 0.23 & 32.6 & 0.22 & 54.1 & 0.13 & 9.4 \\
\hline 2 & Tikkurila & 12.4 & 112.0 & 0.20 & $25 C .0$ & 0.56 & 467.0 & 0 & 47.7 \\
\hline 3 & Tikkurila & 45.5 & 250.0 & 0.42 & 69.5 & 0.27 & 362.0 & 0.52 & 15.4 \\
\hline 4 & Tikkurila & 50.7 & 436.0 & 0.31 & 165.6 & 0.18 & 163.0 & 0.05 & 35.0 \\
\hline 5 & Tikkurila & 44.2 & 260.0 & 0.27 & 118.0 & 0.38 & 268.0 & 0.22 & 38.4 \\
\hline 6 & Tikkurila & 49.4 & 414.0 & 0.27 & 69.4 & 0.09 & 61.4 & 0.32 & 10.2 \\
\hline 11 & Messukylä & 41.8 & & 0.50 & & 0.37 & & 0.29 & \\
\hline 12 & Aitolahti & 43.6 & & 0.05 & & 0.19 & & 0.19 & \\
\hline 13 & Säynäjärvi & 42.8 & & 0.33 & & 0.24 & & 0.03 & \\
\hline 14 & Orivesi & 47.8 & & 0.17 & & 0.45 & & 0.06 & \\
\hline 16 & Tuira & 23.3 & & 0.12 & & 0.12 & & 0.18 & \\
\hline 17 & Kello & 17.4 & & 0.12 & & 0.11 & & 0.22 & \\
\hline 18 & Haukipudas & 13.2 & & 0.36 & & 0.31 & & 0.03 & \\
\hline 19 & Ii & 22.9 & & 0.26 & & 0.29 & & 0.06 & \\
\hline 20 & Olhava & 20.4 & & 0.38 & & 0.17 & & 0.03 & \\
\hline 29 & Salla & 36.1 & & 0.15 & & 0.31 & & 0.63 & \\
\hline 30 & Kemijärvi & 20.6 & & 0.17 & & 0.19 & & 0.05 & \\
\hline 31 & Kaamanen & 16.9 & & - & & - & & - & \\
\hline 32 & Ilomantsi & 15.0 & & 0.23 & & 0.14 & & 0 & \\
\hline
\end{tabular}


tää KURKI (1972) viljelymaan vaihtuvan mangaanin pitcisuuksiksi $\mathbf{3 . 4 - 5 2 . 5}$ mg/l. Korkeimmat pitoisuudet hän totesi maissa, missä orgaanisen aineksen määrät ovat suurimmat. Tässä tutkimuksessa havaittuja happoliukoisen mangaanin pitoisuuksia esitetään taulukossa 4. Korkeimmat pitoisuudet olivat lähinnä lyijynsulattamoja (n:o 2, 4), maassa $112.0-436.0 \mathrm{mg} / \mathrm{kg} \mathrm{k}$-a, salaatissa $165.6-250.0$, pinaatissa $268.0-467.0$ ja porkkanassa $38.4-47.7$ $\mathrm{mg} / \mathrm{kg} \mathrm{k-a.}$

\section{Tulosten tarkastelu}

Määritettäessä raskasmetallien ja eräiden näiden kaltaisten aineiden pitoisuuksia ravintokasveissa lähdettiin niistä tutkimuksista, joita on julkaistu laskeumista eri paikkakunnilla (LAAMANEN 1973). Vertailua varten valittiin perustasopaikkakunniksi Pertunmaan Laukkalan kylä sekä Punkasalmi, jossa laskeumista on olemassa tietoja, lisäksi oletettiin "puhtaiksi" paikkakunniksi Puumala, Maaninka, Saarijärvi, Salla, Rovaniemen maalaiskunta sekä Inari. Näillä paikkakunnilla ei ole teollisuutta, ja koealat sijoitettiin niissä vähintään 300 metrin päähän kaikista liikenneväylistä. Mainituilla paikkakunnilla todettiin tutkimuksissa raskasmetallipitoisuuksia sekä ravintokasveissa että viljely- ja metsämaassa, mikä johtunee ilman mukana kauempaa kulkeutuvista hiukkasista tai maa- ja kallioperän luontaisista pitoisuuksista. Pertunmaan Laukkalan kylässä on LAAMANEN (1973) todennut suurimmaksi lyijyn kuukausilaskeumaksi kesäkuussa $70 \mathrm{mg} / 100 \mathrm{~m}^{2}$, kun se Tikkurilassa lyijytehtaan läheisyydessä oli keskimäärin $20000 \mathrm{mg} / 100 \mathrm{~m}^{2}$. kk. Vastaavilla kohdilla olivat tämän tutkimuksen mukaan maan lyijypitoisuudet 8.9 ja $583.7 \mathrm{mg} / \mathrm{kg} \mathrm{k-a}$. Teollisuuden vaikutusta elohopean esiintymiseen kuvaavat LAAMASEN (1973) esittämät Hg-laskeumat Oulussa, jossa $600 \mathrm{~m}: n$ päässä tehtaasta oli laskeuman määrä keskim. $3 \mathrm{mg}$ ja tehtaasta $2500 \mathrm{~m}: n$ päässä koilliseen $0.5 \mathrm{mg} / 100 \mathrm{~m}^{2}$. kk. Saman matkan päässä tehtaasta, Tuirassa oli tässä tutkimuksessa viljelymaan $\mathrm{Hg}$-pitoisuus keskimäärin $0.17 \mathrm{mg} / \mathrm{kg} \mathrm{k}$-a., $5 \mathrm{~km}$ :n päässä Kellossa 0.12 ja $10 \mathrm{~km}: n$ päässä Haukiputaalla $0.10 \mathrm{mg} / \mathrm{kg}$.

Teollisuuslaitosten ja asutustaajaman vaikutukset maan ja ravintokasvien pitoisuuteen näkyvät lyijyn, kadmiumin, sinkin ja arseenin pitoisuuksien osalta selvimmin $0-5 \mathrm{~km}: \mathrm{n}$ etäisyydellä saastelähteestä. Moottoriteiden saastuttava vaikutus sen sijaan ei ollut selvä Lahden, Turun ja Naantalin moottoriteiden varrella. Tämä saattaa johtua suhteellisen pienestä ajoneuvomäärästä näillä tieosuuksilla. USA:ssa pidetään alle 1000:a ajoneuvoa vuorokaudessa "puhtaana" määränä, sen sijaan yli 70000:n ajoneuvon lukumäärää jo pahoin saastuttavana (ERving et al. 1974). Moottoriajoneuvojen poistamat raskaat metallit, joista lyijy ja kadmium ovat tärkeimmät, saattavat sekä USA:ssa että Saksassa (VETTER et al. 1973) suoritettujen tutkimusten mukaan levitä $150 \mathrm{~m}: n$ etäisyydelle molemmin puolin maantien reunasta lukien.

Tutkimukseen otetut salaatti-, pinaatti- ja porkkananäytteet pestiin välittömästi näytteenoton jälkeen. Pesemällä voidaan suoritettujen kokeiden mukaan vähentää lehtivihannesten Pb-, Cd-, Cu- ,Mn-, S- ja As-pitoisuuksia $12-45 \%$ :lla. Kahdesta pesutavasta tehokkaampi näissä kokeissa oli upotus veteen viidesti. Kuta kauemmin hiukkaset ovat olleet kasvin pinnalla sitä 
vähäisempi osa siitä on pesemällä poistettavissa. Myös jatkuvien sateiden on todettu vähentävän lehtivihannesten raskasmetallipitoisuuksia (HoRAK et al. 1974).

Tutkituista ravintokasveista sisälsivät saastuneessa maassa kasvaneet salaatti ja sienet eniten raskasmetalleja. Tästä syystä on niiden kelpoisuus ravinnoksi kyseenalaista niillä paikkakunnilla, missä maan Cd-pitoisuudet ovat enemmän kuin $0.50 \mathrm{ppm} \mathrm{k-a}$. ja Pb-pitoisuudet yli $50 \mathrm{ppm}$ k-a. Porkkanan pitoisuudet ovat verraten alhaiset saastuneessa maassa, samoin metsämarjojen. Viimeksi mainituista mustikan pitoisuudet ovat hieman korkeammat kuin puolukan. Laidunruoho oli tutkituilla alueilla varsin puhdasta. Koska koealojen lukumäärä kaikkiaan oli vain 52, ei päätelmiä raskasmetallien alueellisista pitoisuuksista Suomessa voida tehdä. Koealat valittiin kuitenkin vain saastelähteiden vaikutuksien sekä toisaalta "puhtaiden" alueiden tausta-arvojen selvittämiseksi. Kansanterveyden kannalta olisi kuitenkin koko maan kattava jatkuva seurantatutkimus välttämätön.

\section{Yhteenveto}

Ravintokasvien ja niiden kasvupaikassa maan raskasmetallipitoisuuksia tutkittiin 52:lla koealalla eri puolilla Suomea. Samalla tutkittiin Ca-, K- ja Mglannoituksen vaikutusta salaatin, pinatin ja porkkanan pitoisuuksiin sekä korjuun jälkeen tapahtuvan pesun puhdistavaa tehoa salaatin pitoisuuksissa.

Keskimäärin ovat ravintokasvien, salaatin, pinaatin, porkkanan, puolukan, mustikan ja sienten pitoisuudet meillä alhaisempia kuin Keski-Euroopan maissa. Myös viljely- ja metsämaan raskasmetallipitoisuudet olivat alhaisempia.

Teollisuuslaitosten, asutustaajamien ja vilkkaiden liikenneväylien välittömässä läheisyydessä oli kasveissa ja maassa tausta-arvoja korkeampia pitcisuuksia. Suuren teollisuuslaitoksen vaikutus näkyi $10 \mathrm{~km}: \mathrm{n}$ päähän, ja lähempänä kuin $5 \mathrm{~km}: \mathrm{n}$ päässä voivat raskasmetallipitoisuudet olla varteenotettavan korkeita.

Kalkitus vähensi vihannesten $\mathrm{Pb}$ - ja $\mathrm{Cd}$-pitoisuutta, upottamalla salaatti veteen viidesti vähenivät pitoisuudet $38-44 \%$ :lla. Vihanneskasveista salaatti ja metsäkasveista sienet ottavat maasta eniten raskasmetalleja.

Turun ja Lahden moottoriteiden varrella olivat lehtivihannesten raskasmetallipitoisuudet korkeimmat 5 m:n etäisyydellä tien reunasta. Maan pitoisuuksissa ei liikenteen vaikutusta ollut havaittavissa.

\section{KIRJALLISUUSLUETTELO}

Bouchard, A. 1973. Determination of mercury after room temperature digestion by flameless atomic absorption. AAS-newsletter 12,5: 115.

Bouguiaux, J. 1973. Non-organic micro-pollutants of the environment I. 34 p. Brussels.

Dissing, J. 1972. Cadmium i jord og planter. Ugeskrift for agronomer og hortonomer 1: 953954.

ERvıö, R. \& LAKANEN, E. 1973. Maan lyijysaastuminen sulattamon ympäristōssä Tikkurilassa. Ann. Agr. Fenn. 12: 200-206. 
Ewing, B. B. \& Pearson, J. E. 1974. Lead in the environment. Advances in environmental science and technology 3: 1-126.

Frank, R., IshidA, K. \& SudA, P. 1976. Metals in agricultural soils of Ontario. Can. J. Soil Sci. 56: $181-196$.

Hemkes, O. J. \& Hartmans, J. 1974. Copper content in grass and soil under high-voltage lines in industrial and rural areas. Trace Substances in Environmental Health 7: $167-174$.

HoraK, O. \& Huber, I. 1974. Verunreinigung von Pflanzen und Böden durch Bleirückstände aus Benzinmotoren. Die Bodenkultur 25: 34-47.

Hvatum, О. Ø. 1972. Fordeling av bly og endel andre tungmetaller i ombrogen torv. Symp. om tungmetallforurensninger 1972: 59-70.

Jалккоla, Т., Таканаshi, H. \& Mietrinen, J. 1973. Cadmium content in sea water, bottom sediment, fish, lichen, and elk in Finland. Environmental Quality and Safety: 230237. Stuttgart.

KLоKe, A. 1972. Zur Anreicherung von Cadmium in Böden und Pflanzen. Landw. Forsch. Sonderh. 27/1: 200-206.

KURKI, M. 1972. Suomen peltojen viljavuudesta II. 182 s. Helsinki.

LAAMANEN, A. 1972. Ilmaympäristösaasteet maataloustuotannon kannalta. 41 s. Moniste.

LAKANEN, E. 1966. Separation and concentration of trace metals by means of pyrrolidine dithiocarbamic acid. AAS-newsletter 5, 2: 17.

LÁ, J. 1972. Norsk jordbunnforskning i relasjon til problemer om naturforurensning med tungmetaller. Symp. om tungmetallforurensninger 1972: $52-57$.

McLean, A. J. 1976. Cadmium in different plant species and its availability in soils as influenced by organic matter and additions of lime, P, Cd and $\mathrm{Zn}$. Can. Jour. Soil Sci. 56,3: 129-138.

Nylands svenska lantbrukssällskap 1973. En undersökning av jorden och växtligheten kring Ingå kraftverk. 5 s. Stencil.

Official Methods of Analysis of the Association of Official Agricultural Chemists. 965 p. Washington.

Purves, D. 1972. Consequences of trace-element contamination of soils. Environ. Pollut. 3: $17-24$.

RautapäÄ, J. 1973. Cadmium: production, use and residues in the environment in Finland. Kemian teollisuus 10:465-467.

Statens Lantbrukskemiska Laboratorium 1974. Metoder för tungemetallanalyser utom kvicksilver, 2 s. Stencil.

Warnusz, J. 1973. Feldversuche zur Nachwirkung von Blei-, Chrom-, Kupfer- und Zinkhaltigen Abwasserklärschlämmen bei Grünland und Getreide sowie Gefässversuche zur Aufnahme von Cadmium und Zinn. Diss., 117 S. Bonn.

Vetter, H., Mählhop, R. \& Früchtenicht, K. 1973. Immissionsbelastung im Raum Nordenham. Landw. Untersuchungs- und Forschungsanstalt der Landw. Kammer WeserEms. $30 \mathrm{~S}$. Oldenburg.

Williams, C. H. \& DAvid, D. J. 1976. The accumulation in soil of cadmium residues from phosphate fertilizers and their effect on the cadmium content of plants. Soil Science 121,2: 86-93.

ØDELIEN, M. 1974. Spørsmâl omkring noen tungmetaller i jord, kulturvekster, husdyr og mennesker. Ny jord 61,1: 22-33.

Käsikirjoitus saapunut 2.5.1977. 